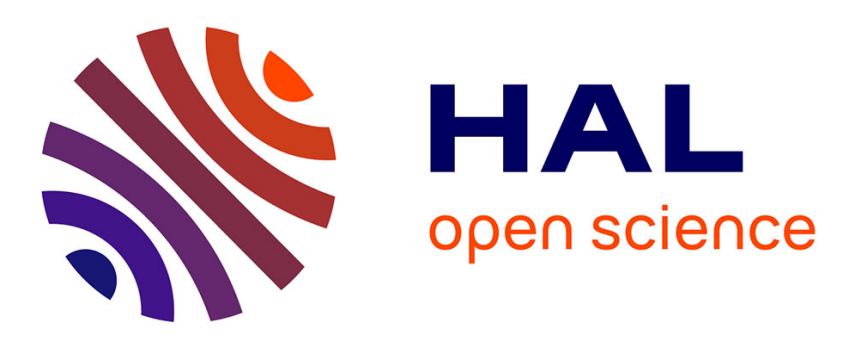

\title{
High-Resolution Archaeoenvironmental Study of a Cultic Episode at a Statue-Menhir Copper Age Site (Ossimo Anvòia, Italian Alps)
}

Emilia Allevato, Francesco Fedele, Filippo Terrasi, Manuela Capano, Gaetano Di Pasquale

\section{- To cite this version:}

Emilia Allevato, Francesco Fedele, Filippo Terrasi, Manuela Capano, Gaetano Di Pasquale. HighResolution Archaeoenvironmental Study of a Cultic Episode at a Statue-Menhir Copper Age Site (Ossimo Anvòia, Italian Alps). Radiocarbon, 2013, 55 (1), pp.49-58. 10.2458/azu_js_rc.v55i1.16063 . hal-01684184

\section{HAL Id: hal-01684184 https://hal.science/hal-01684184}

Submitted on 29 Apr 2019

HAL is a multi-disciplinary open access archive for the deposit and dissemination of scientific research documents, whether they are published or not. The documents may come from teaching and research institutions in France or abroad, or from public or private research centers.
L'archive ouverte pluridisciplinaire HAL, est destinée au dépôt et à la diffusion de documents scientifiques de niveau recherche, publiés ou non, émanant des établissements d'enseignement et de recherche français ou étrangers, des laboratoires publics ou privés. 


\title{
HIGH-RESOLUTION ARCHAEOENVIRONMENTAL STUDY OF A CULTIC EPISODE AT A STATUE-MENHIR COPPER AGE SITE (OSSIMO ANVÒIA, ITALIAN ALPS)
}

\author{
Emilia Allevato ${ }^{1,2}$ • Francesco Fedele ${ }^{3}$ - Filippo Terrasi ${ }^{4,5}$ • Manuela Capano ${ }^{5,6}$ • \\ Gaetano Di Pasquale ${ }^{1}$
}

\begin{abstract}
Nine excavation seasons at Ossimo Anvòia in the Val Camonica (Central Alps, Italy) have brought to light a Copper Age ceremonial area with symbolic monoliths (statue menhirs) in their original position. Hundreds of artifacts and ecofacts indicate ideological activity during the 3rd millennium BC. A large pit (F18) was discovered that was unusual for its great size and the abundance of well-preserved charcoal. The pit housed a fallen monolith (M9) showing complicated reshaping. A detailed spatial study based on 6 radiocarbon accelerator mass spectrometry (AMS) measurements combined with charcoal analysis has untangled key information to define the history of feature F18-M9. ${ }^{14} \mathrm{C}$ data show that the burning event occurred most probably in the 4th century AD, not in prehistory. We infer a unique episode of "reconsecration" during the very latest phases of pagan cult activity in the Val Camonica. Further studies are needed to resolve the relationships with other features of the site. In addition, charcoal analysis has produced paleobotanical information for a scarcely known period in the environmental history of the area. A sparse forest with Picea abies, Larix decidua, and Fagus sylvatica existed, associated with areas likely devoted to grazing. There is a remarkable absence of chestnut.
\end{abstract}

\section{INTRODUCTION}

Extensive excavations between 1988 and 2002 have brought to light an open-air cultic or ceremonial area of the Copper Age ( 2800/2700-2200 BC; Fedele 2006, 2008) at Anvòia, near Ossimo on the Borno Plateau (Val Camonica, Central Alps; Figure 1B and C). The site is an expression of a particular ideological manifestation or "cycle" (Fedele 2011) characterizing the Alpine and circumAlpine regions during that period.

Several statue menhirs (large standing stones with engraved and possibly painted symbolic figures) were found, some of them in their original position. Also prominent among the findings was the probable ritual manipulation of human skeletal remains, partly charred, which suggests connections between statue-menhir sites, funerary ritual, and the ancestors' cult. Statue menhirs and some related sites had been discovered in the Alps between the Adige Valley and Lake Geneva, notably at Sion in Canton Wallis and at Aosta in the Aosta Valley (Figure 1A), but Anvòia was the first central Alpine site in which these monuments had been found in their primary context. The Ossimo-Anvòia archaeological program was focused on human behavior and site function, and striving to reach a better understanding of statue-menhir iconography; the latter was studied in detail as a vital and complementary class of archaeological data (Fedele 2008 and references therein).

This paper is specifically concerned with an extraordinary feature of the site, a large pit (F18) with a complicated history into which a roughed-out menhir was eventually lodged (M9) (Figure 2). M9 is the remnant of an earlier statue menhir, and the pit is lined with spalls from flaking the monolith. Unusually abundant charred wood was found intercalated with the spalls, stones, and sediments filling the pit. The F18-M9 feature is located in the "focal area" of the ceremonial site ( 135 m²; Figure 2) where higher find-density was observed.

\footnotetext{
${ }^{1}$ Università di Napoli Federico II, Dip. Arboricoltura Botanica e Patologia Vegetale, Naples, Italy.

${ }^{2}$ Corresponding author. Email: eallevat@unina.it.

${ }^{3}$ Retired. Formerly at Università di Napoli Federico II, Cattedra e laboratorio di Antropologia, Portici (NA), Italy.

${ }^{4}$ Dipartimento di Matematica e Fisica, Seconda Università di Napoli, Caserta, Italy.

${ }^{5}$ INNOVA - CIRCE (Centre for Isotopic Research on Cultural and Environmental heritage), Caserta, Italy.

${ }^{6}$ Dipartimento di Lettere e Beni Culturali, Seconda Università degli Studi di Napoli, Santa Maria Capua Vetere, Caserta, Italy.
} 


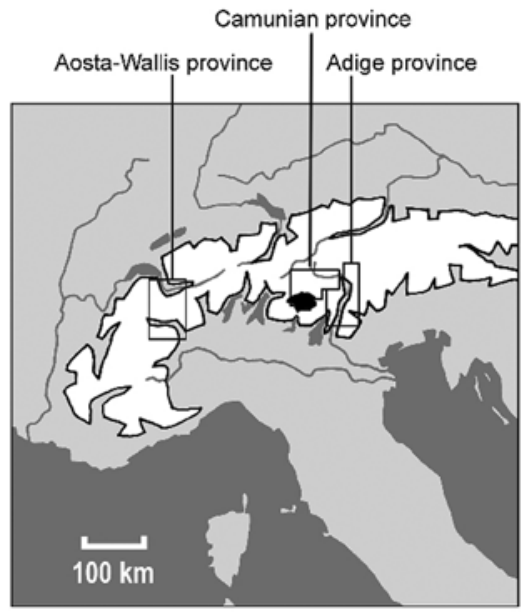

A)

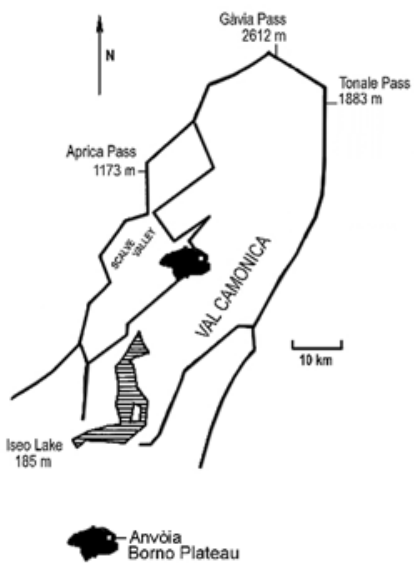

B)

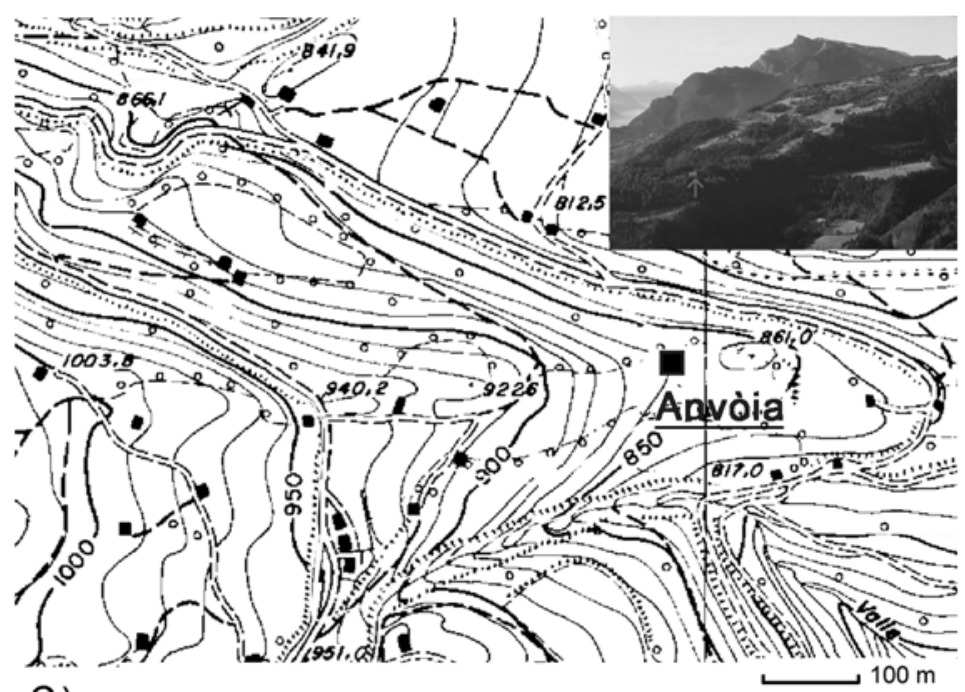

C)

Figure 1 A) The 3 main provinces of Alpine statue menhirs: Aosta-Wallis, Camunian, and Adige; B) the Borno Plateau within Val Camonica; C) location of the Anvòia site.

Concomitant to the revelation from radiocarbon dating that the burning in the pit was unrelated to the Copper Age, we report here a spatially detailed study of F18-M9 based on charcoal analysis coupled with ${ }^{14} \mathrm{C}$ measurements. A preliminary reassessment of the archaeological evidence in the light of these results is also presented.

\section{Present Vegetation}

Anvòia is the name of a small west-to-east ridge on the northeastern Borno Plateau, on which the archaeological site (coded OS4) is located at an elevation of $\sim 850 \mathrm{~m}$ asl (Figure $1 \mathrm{~B}$ and C). The plateau is part of the mountainous interfluve between the Val Camonica and a lesser furrow to the west, the Scalve Valley. The present vegetation at Anvòia and in its close surroundings is represented by Picea abies, the remains of chestnut plantations, and the occasional birch. 


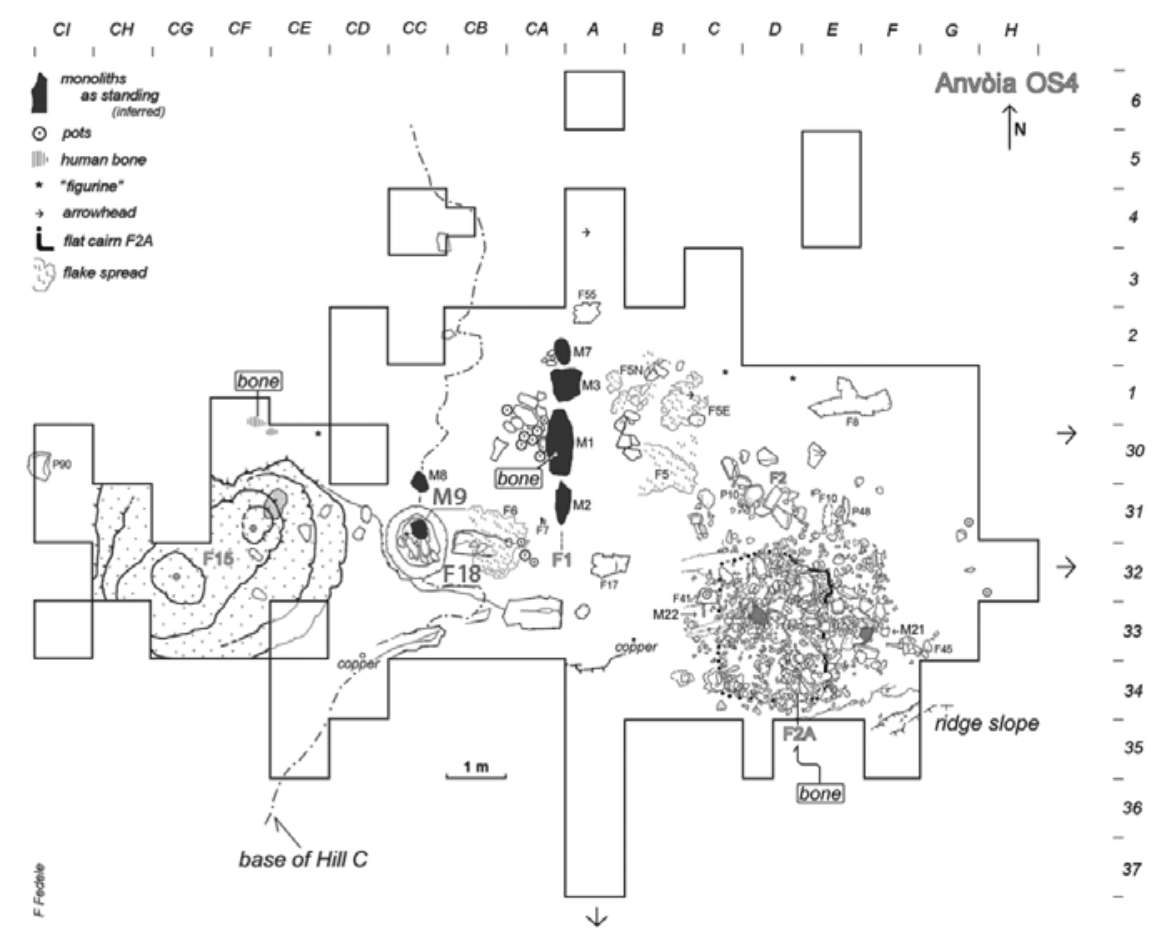

Figure 2 Simplified excavation plan of the functionally defined "focal area," and location of pit F18 and statue-menhir M9 (west of center).

Along the plateau, chestnut plantations occupy the lower altitudes up to $~ 850 \mathrm{~m}$ asl. At higher elevations, conifer woods with Picea abies, Larix decidua, and sporadically Pinus sylvestris prevail; meadows are also present. Fagus sylvatica and Abies alba are scarce.

\section{MATERIALS AND METHODS}

\section{Charcoal Analysis}

High-resolution excavation procedures were employed at Anvòia (Fedele 2008). All the contents of pit F18, including charcoal fragments, were systematically retrieved by hand and by flotation and labeled according to their spatial and stratigraphic position (e.g. 333.10, with 333 being the dissection unit or "cut" and 10 the spatial "position" within the sediment volume of the cut). Charcoals coming from 10 sediment samples and 7 localized/concentrated samples, in 10 stratigraphic cuts, (Figure 3) were identified by an incident light microscope working between 100 and 1000 magnification, with use of 2 wood atlases (Greguss 1955, 1959; Schweingruber 1990) and the reference collection of the Vegetation History and Wood Anatomy Laboratory of Naples University. Percentages of each taxon were calculated from the total of analyzed charcoal fragments in each cut. Post-excavation fragments belonging to the same original element were calculated as one.

\section{Radiocarbon Dating}

Six charcoal fragments were ${ }^{14} \mathrm{C}$ dated by accelerator mass spectrometry (AMS), the first two in 2007 (8.14 and 9.22) before we started the identification work. For these 2 samples, identification was possible only for sample 8.14 since a fragment belonging to the same original element had been preserved. 


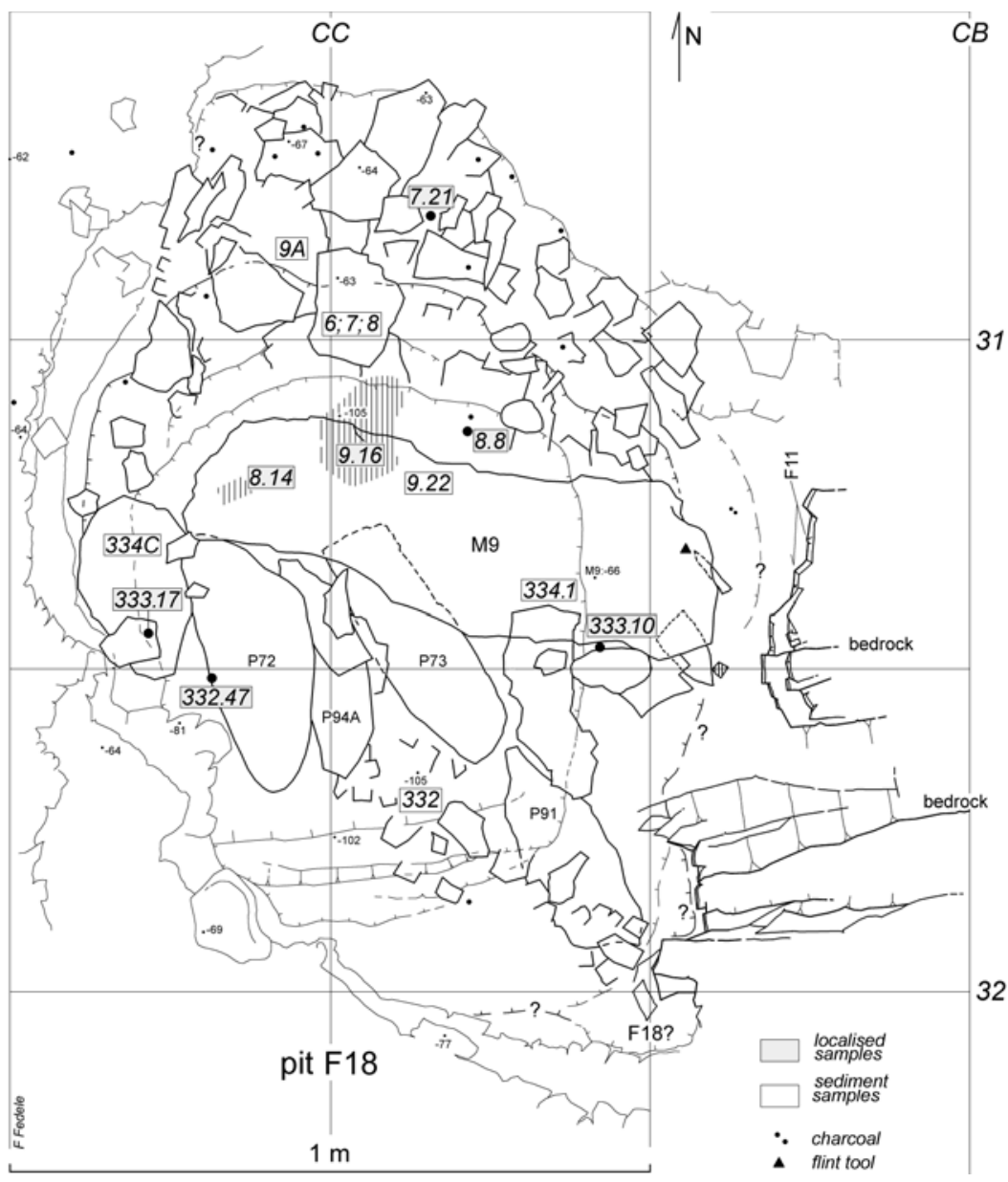

Figure 3 Plan of pit F18 and the location of the samples studied

In 2011, as part of the charcoal analysis, 4 more samples were selected-for verification and additional testing - according to both position in the pit and taxon in order to investigate the relationships between chronology, stratigraphy, and cultural wood selection. Dating was conducted at the Center for Isotopic Research on Cultural and Environmental Heritage (CIRCE), INNOVA, Seconda Università di Napoli, with the equipment and methods described elsewhere (Passariello et al. 2007; Marzaioli et al. 2008; Terrasi et al. 2008).

Conventional ${ }^{14} \mathrm{C}$ ages were calibrated using the OxCal v 4.1.7 program (Bronk Ramsey 2009) and the IntCal09 calibration curve data (Reimer et al. 2009). In order to better constrain the burning event(s), the ${ }^{14} \mathrm{C}$ dates were also tentatively pooled into different groupings using the R_Combine function of OxCal (Bronk Ramsey 2009).

\section{RESULTS}

\section{Charcoal Analysis}

The identified taxa are Fagus sylvatica, Juniperus, Picea/larix, and cf. Larix decidua (Figure 4). Distinguishing Picea abies and Larix decidua by their wood anatomy is notoriously difficult 
because the only diagnostic characteristic is the shape of pit exterior borders in the ray tracheids (Bartholin 1979; Schweingruber 1990; Anagnost et al. 1994; Talon 1997; Jagels et al. 2001). In our case, a distinction between Picea abies and Larix decidua could not be finalized because the size of the charcoal finds did not allow to observe a sufficient number of bordered pits in the ray tracheids. However, some charcoal specimens appear more likely to belong to Larix decidua than to Picea abies; thus, "cf. Larix decidua" is listed as a taxon in addition to Picea/Larix.

The taxa seem to have a differential distribution within the pit's fill, with Picea/Larix and cf. Larix decidua prevailing in the southern part and Fagus sylvatica being the most common species in the northern part. Juniperus is present in low percentages towards the base of the fill below $75 \mathrm{~cm}$ depth (Figure 4).

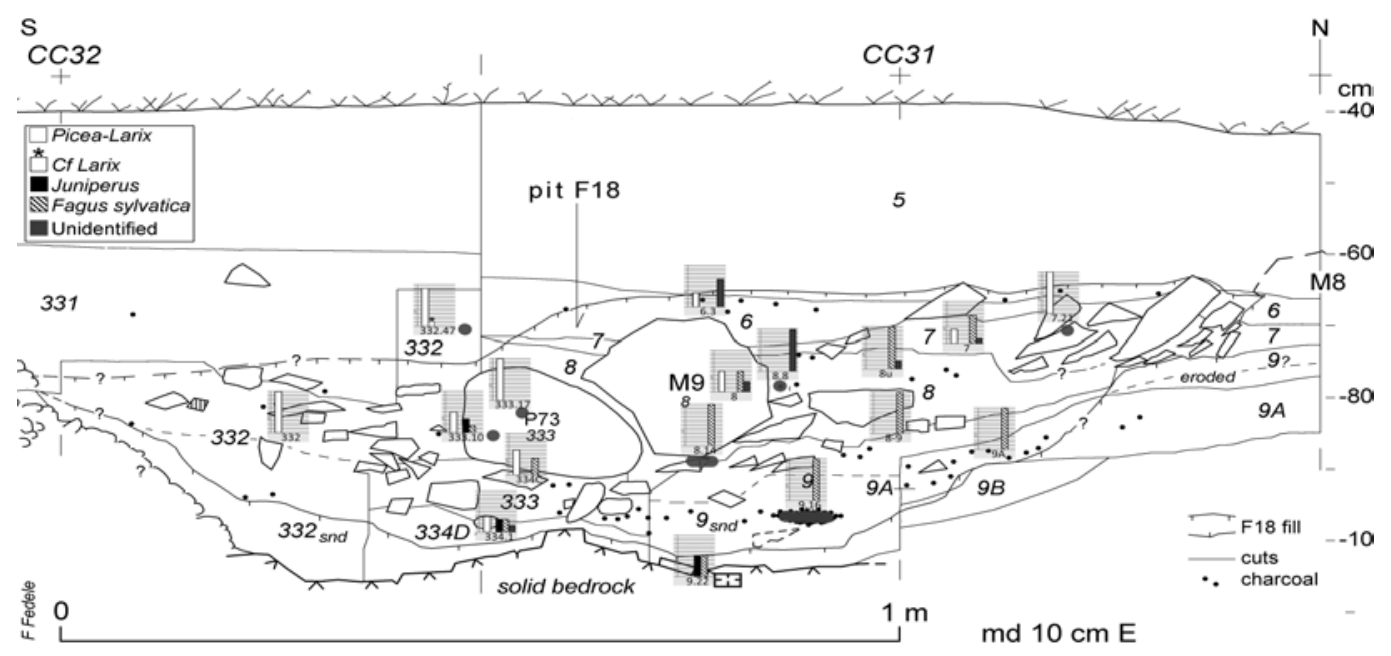

Figure 4 Identified taxa and their vertical distribution within pit F18. The lines represent stratigraphic "cut" boundaries. Gray dots and ellipses indicate the position of localized/concentrated samples.

\section{Radiocarbon Dating}

The 6 single-fragment charcoal samples from pit F18 gave calendar year dates, after calibration at $2 \sigma$ intervals, ranging from the mid-1st to the early 6th century AD (Table 1, Figure 5). At the moment, no charcoal date falling in the 3rd millennium BC-the Copper Age utilization of the site- has been obtained (see Fedele et al. 2010 for details on all presently available ${ }^{14} \mathrm{C}$ measurements from Anvòia).

Table 1 Results of ${ }^{14} \mathrm{C}$ measurements.

\begin{tabular}{llll}
\hline Sample $\mathrm{nr}$ & Taxon & ${ }^{14} \mathrm{C}$ age BP & Calendar age AD $(2 \sigma)$ \\
\hline 8.14 & Fagus sylvatica & $1694 \pm 77$ & $139-538$ \\
9.22 & Unidentified & $1694 \pm 18$ & $259-410$ \\
332.47 & Picea/Larix & $1923 \pm 20$ & $28-127$ \\
333.10 & Picea/Larix & $1787 \pm 19$ & $138-324$ \\
334.1 & Juniperus & $1724 \pm 19$ & $254-383$ \\
333.10 & Juniperus & $1661 \pm 49$ & $256-534$ \\
\hline
\end{tabular}




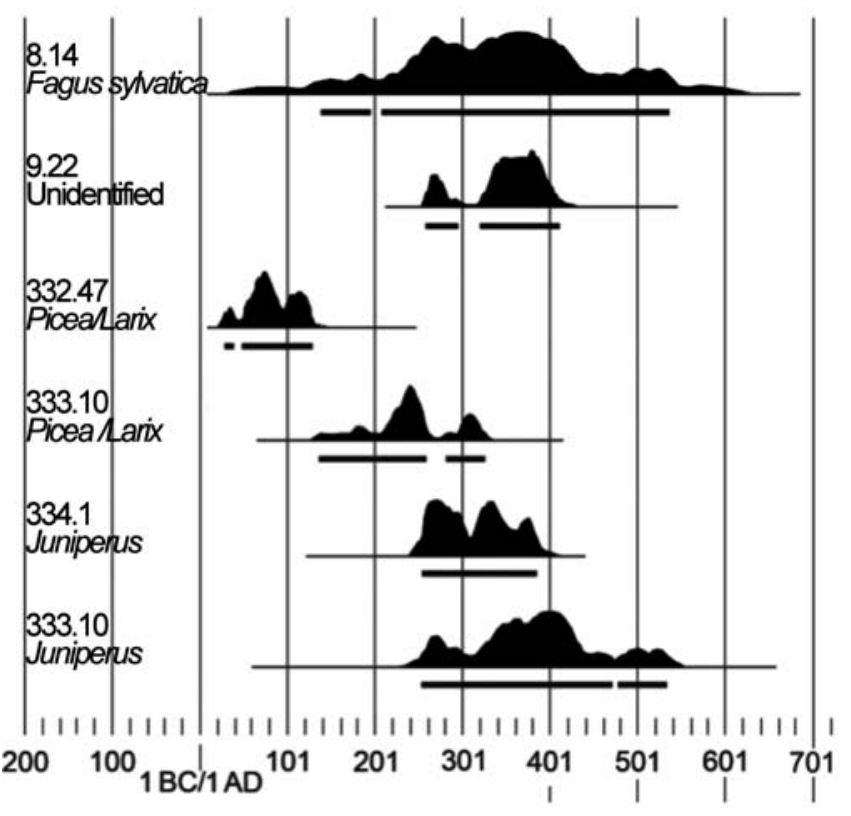

Figure 5 Multiplot graph of calendar ages (modified after Fedele et al. 2010)

The Picea/Larix dates span the mid-1st to early 4th century AD interval, while the Juniperus dates to the mid-3rd to early 6th century AD. Fagus sylvatica is distributed between the 2nd-6th century $\mathrm{AD}$, as a result of a larger uncertainty in the ${ }^{14} \mathrm{C}$ age measurement (8.14), and an unidentified sample (9.22) dates to the mid-3rd to early 5th century AD (Table 1, Figure 5).

Results obtained for all dated samples could not be combined since the $\chi^{2}$ test failed with $<5 \%$ probability of this being a good combination [ $\chi^{2}$ test: $d f=5, p=89.7$ (5\%: 11.1)]. However, good statistical significance $\left[\chi^{2}\right.$ test: $d f=3, p=2.2$ (5\%: 7.8)] was obtained by excluding the Picea/Larix data, resulting in a combined date of AD 258-395 with a $71.8 \%$ probability of belonging to the AD 320395 interval and 23.6\% probability of belonging to AD 258-297 (Fedele et al. 2010) (Figure 6).

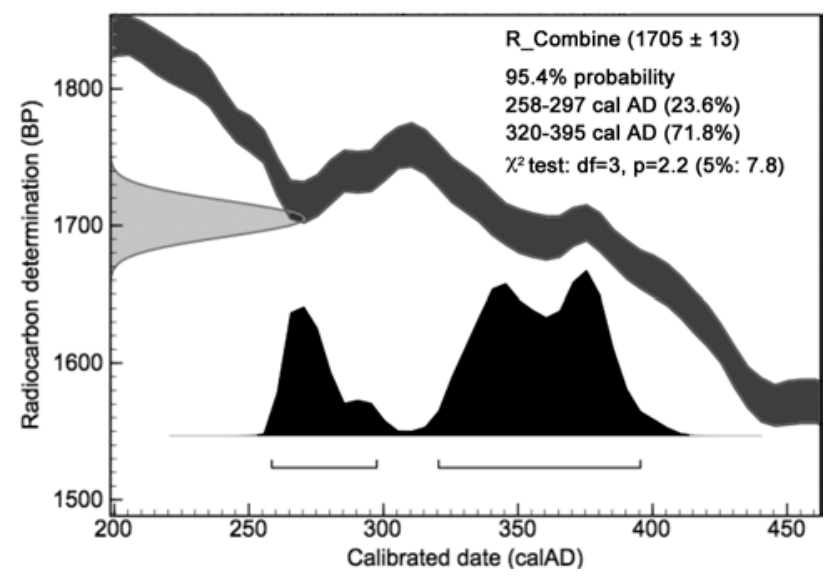

Figure 6 OxCal plot of the combined date of samples 8.14 Fagus sylvatica; 9.22 (unidentified); 334.1 Juniperus; and 333.10 Juniperus. 


\section{DISCUSSION}

\section{Chronology}

The ${ }^{14} \mathrm{C}$ data obtained led to unexpected new vistas on the history of pit F18 and its unusual contents. The fire(s) responsible for the abundant charcoal did not occur in the 3rd millennium BC, as was inferred from the general Copper Age context, but in the late Roman or the Late Antiquity period.

In order to estimate a probable calendar age for the burning event, we tentatively combined all ${ }^{14} \mathrm{C}$ dates using the OxCal function R_Combine, but the $\chi^{2}$ test indicated that this combination should be rejected at the $5 \%$ confidence level. A consistent result was instead obtained by excluding from the test the 2 oldest samples, both of Picea/Larix (332.47 and 333.10). It is interesting that the $\chi^{2}$ test also failed when we tried to combine the 2 dates from Picea/Larix wood. We therefore suggest this is a case of the well-known "old wood" problem-e.g. a charcoal fragment coming from the innermost heartwood giving a date long before the time the tree was cut down (Schiffer 1986; Taylor 1987; Bowman 1990). It seems conceivable that the dated charcoal fragments from this long-lived

tree belonged to interior heartwood portions developed some centuries before the time when the wood was burned.

As a consequence, in spite of the initial impression that the charcoal in pit F18 had originated from at least 3 distinct burning events, there is reason to infer that a single burning event had occurred, this also being the most parsimonious explanation. To this event, we attribute the combined date of AD 258-395 obtained from the non-Picea/Larix samples, including Juniperus, Fagus sylvatica, and the unidentified taxon. However, producing from a historical point of view an even more persuasive connection of the F18 event with a pagan "reconsecration" ceremony at the site (Fedele et al. 2010; see below), we argue that the fire originating the F18 charcoal should be placed in the AD 320-395 interval, at $71.8 \%$ probability (Figure 6).

\section{Cultural and Historical Context}

Since no field evidence of further activity at the site after the 3rd millennium BC was recorded, one is compelled to infer a rediscovery of the Anvòia site in the 3rd or more probably the 4th century $\mathrm{AD}$. This represents an entirely new chapter not only in the archaeological record of the Borno Plateau, but to some extent in the entire Val Camonica. Considering ceremonial contexts, occasional activities during the Iron Age and the Roman period have been reported from 2 statue-menhir sites recently excavated in the valley, Ossimo Pat and Capo di Ponte Massi di Cemmo (Poggiani Keller 2009). However, neither of these sites shows the same kind and degree of ideological complexity, quite possibly of a cultic nature, as that displayed by Anvòia F18: the idiosyncratic hammering of monolith M9, its re-erection within a flake-lined pit accompanied by heavy burning, and the probable reshaping of the pit itself (F Fedele, data on file).

Val Camonica and some of the adjoining regions were reached relatively late by the processes of Christianization (not before the 5th century AD; Valvo 1991). Although information is limited, in both the Val Camonica and the Adige Valley the decades around AD 400 saw a cessation of the sanctuaries devoted to pagan cults, with generalized abandonment (e.g. in Val Camonica, Breno Spinera, Borno Calagno, Capo di Ponte Le Sante; Solano 2007, 2008; cf. Fedele et al. 2010:28). It is difficult to determine whether the Anvòia episode is best explained by reconsecration or desecration. However, no obvious hints of Christianizing behavior can be perceived in the available evidence. Our preferred interpretation at the moment points to a pagan ceremony of reconsecration, or a closely 
spaced suite of ceremonies, enacted when such an "immemorial" site was rediscovered at Anvòia. This fascinating topic will be pursued in the future.

The sampling procedure allowed a detailed spatial distribution of the taxa to be examined. However, no substantial difference exists between the southern and northern parts of pit F18, respectively dominated by Picea/Larix and Fagus sylvatica (Figure 4). Some interesting considerations about the use of different species can be derived from the positioning of charcoal assemblages in the vertical section of the pit. The presence of Juniperus charcoal exclusively below $75 \mathrm{~cm}$ depth, towards the bottom of the pit, suggests that it was used for lighting the fire, a choice that is consistent with both its branch size and high flammability.

Further research supported by ${ }^{14} \mathrm{C}$ dating of additional material would be necessary to understand in greater depth the behavioral-ideological circumstances in which both the burning in pit F18 and the reshaping of statue-menhir M9 took place.

\section{Vegetation History}

The vegetation history of the Val Camonica is still poorly known due to a very limited number of pollen analyses and a lack of more comprehensive paleobotanical studies. Furthermore, useful sediments from the Roman-Late Antiquity period are virtually lacking (Gehrig 1997). Pioneering pollen analysis carried out at Anvòia itself (Mori Secci 1995), in conjunction with a pedological survey (R Comolli, S Chersich, F Previtali, unpublished), provide a very interesting sequence (cf. Fedele 2006; data with the Ossimo Programme) but inevitably lack precise chronological control.

The data presented in this paper indicate the presence of Fagus sylvatica and continental and microtherm conifers during the late Roman/Late Antiquity period. The beech today is scarcely represented in the Val Camonica because in recent times it has been substituted with Picea abies due to its greater economic worth (Pini and Ravazzi 2009). However, Gehrig (1997) suggests that the present reduction of Fagus may be due to intensive clearing of the beech forest in the Medieval period, when suitable firewood was greatly needed for the iron melting furnaces.

The occurrence of coupled Juniperus and Larix decidua wood in our charcoal assemblages suggest intensive grazing, as also reported by Pini (2002) for the late Roman period and more generally by Gehrig (1997). As these heliophilous trees are unable to grow in dense woodland, we would infer that the landscape surrounding the site was a kind of savanna (sensu Grove and Rackham 2001), i.e. a wood pasture consisting of scattered trees among other types of vegetation such as grassland.

Finally, it is interesting to note that chestnut does not appear in our samples, although it is prevalent in the modern landscape. Possibly, the species was not yet present at or near the site, whereas the beginning of the Roman age in the pre-Alpine region is mainly defined by the spread of Juglans regia and Castanea sativa (Mori Secci 1995; Gehrig 1997; Pini 2002).

\section{CONCLUSION}

The Ossimo Anvòia findings highlight the importance of ${ }^{14} \mathrm{C}$ dating for correctly understanding behavioral events beyond the knowledge directly provided by fieldwork and archaeological context. The unexpected dating to the late Roman or Late Antiquity period of a major feature in this Copper Age ceremonial site, pit F18, has revealed an entirely new chapter and ideological episode in the archaeological sequences of the Val Camonica. For the first time of which we are aware, distinct evidence has emerged of a local, complex ideological reaction to the uncovering of prehistoric statue menhirs during the very latest phases of the pagan religion in the central Alps. Some centuries later, 
by contrast, during the full Christian period, ancient statue menhirs were simply destroyed, as Anvòia itself has amply revealed (e.g. Fedele 2006). Concerning Anvòia, the archaeological task is now to identify - through a re-analysis of the excavation data - other possible site alterations connected with this Late Antiquity episode.

High-resolution charcoal analysis of pit F18, supported by ${ }^{14} \mathrm{C}$ dating and in conjunction with the detailed archaeological records, has allowed a reconstruction of several cultural aspects of the Late Antiquity episode. In addition, although preliminary, it provides a well-dated snapshot of the vegetation in the vicinity of the site during the 4th century $\mathrm{AD}$. The forest cover was very different from the present one: at Ossimo Anvòia beech and conifers still existed, some parts of the area were used for grazing, and the present-day chestnut cultivation was still absent. To some extent, these features can probably be extrapolated to large tracts of the eastern Borno Plateau. This information is important in dealing with a scarcely known period in the valley's environmental history.

\section{REFERENCES}

Anagnost SE, Meyer RW, Zeeuw de C. 1994. Confirmation and significance of Bartholin's method for the identification of the wood of Picea and Larix. IAWA Journal 15(2):171-84.

Bartholin T. 1979. Picea-Larix problem. IAWA Bulletin 1:7-10.

Bowman S. 1990. Radiocarbon Dating. Berkeley: University of California Press.

Bronk Ramsey C. 2009. Bayesian analysis of radiocarbon dates. Radiocarbon 51(1):337-60.

Fedele F. 2006. Asinino-Anvòia: il Parco archeologico. Cerveno: Cooperativa Archeologica Le Orme dell'Uomo.

Fedele F. 2008. Statue-menhirs, human remains and mana at the Ossimo 'Anvòia' ceremonial site, Val Camonica. Journal of Mediterranean Archaeology 21(1):57-79.

Fedele F. 2011. Origini dell'ideologia cerimoniale centroalpina dell'età del Rame: una "fase zero" di IV millennio? Notizie Archeologiche Bergomensi 19:77100.

Fedele F, Terrasi F, Capano M. 2010. Datazioni radiocarboniche AMS per l'area a statue-menhir di Ossimo 'Anvòia', Valcamonica: primi risultati. Notizie Archeologiche Bergomensi 18:19-32.

Gehrig R. 1997. Pollenanalytische Untersuchungen zur Vegetations- und Klimageschichte des Val Camonica (Norditalien). Dissertationes Botanicae 276:1-152.

Greguss P. 1955. Identification of Living Gymnosperms on the Basis of Xylotomy. Budapest: Akadémiai Kiadó.

Greguss P. 1959. Holzanatomie der Europäischen Laubhölzer und sträucher. Budapest: Akadémiai Kiadó.

Grove AT, Rackham O. 2001. The Nature of Mediterranean Europe: An Ecological History. New Haven: Yale University Press.

Jagels R, Le Page BA, Jiang M. 2001. Definitive identification of Larix (Pinaceae) wood based on anatomy from the middle Eocene, Axel Heidelberg Island, Canadian High Arctic. IAWA Journal 22(1):73-83.
Marzaioli F, Borriello G, Passariello I, Lubritto C, De Cesare N, D’Onofrio A, Terrasi F. 2008. Zinc reduction as an alternative method for AMS radiocarbon dating: process optimization at CIRCE. Radiocarbon 50(1): 139-49.

Mori Secci M. 1995. La storia dell'ambiente: indagini palinologiche nel sito di Ossimo OS4. In: Fedele F, editor. Ossimo 1: Il contesto rituale delle stele calcolitiche e notizie sugli scavi 1988-1995. Gianico: La Cittadina. p 15-21.

Passariello I, Marzaioli F, Lubritto C, Rubino M, D’Onofrio A, De Cesare N, Borriello G, Casa G, Palmieri A, Rogalla D, Sabbarese C, Terrasi F. 2007. Radiocarbon sample preparation at CIRCE AMS laboratory in Caserta, Italy. Radiocarbon 49(2):225-32.

Pini R. 2002. A high-resolution Late-Glacial-Holocene pollen diagram from Pian di Gembro (Central Alps, Northern Italy). Vegetation History and Archaeobotany 11(4):251-62.

Pini R, Ravazzi C. 2009. Boschi, colture e pascoli nella media Valtellina durante gli ultimi 7 mila anni. Notiziario dell'Istituto Archeologico Valtellinese 7:73-81.

Poggiani Keller R, editor. 2009. La Valle delle Incisioni. Catalogo della mostra, Brescia, marzo-maggio 2009. Brescia: Provincia di Brescia.

Reimer PJ, Baillie MGL, Bard E, Bayliss A, Beck JW, Blackwell PG, Bronk Ramsey C, Buck CE, Burr GS, Edwards RL, Friedrich M, Grootes PM, Guilderson TP, Hajdas I, Heaton TJ, Hogg AG, Hughen KA, Kaiser KF, Kromer B, McCormac FG, Manning SW, Reimer RW, Richards DA, Southon JR, Talamo S, Turney CSM, van der Plicht J, Weyhenmeyer CE. 2009. IntCal09 and Marine09 radiocarbon age calibration curves, 0-50,000 years cal BP. Radiocarbon 51(4): 1111-50.

Schiffer MB. 1986. Radiocarbon dating and the "old wood" problem: the case of the Hohokam chronology. Journal of Archaeological Science 13(1):13-30.

Schweingruber FH. 1990. Anatomy of European Woods. Stuttgart: Paul Haupt. 
Solano S. 2007. Forme minori del popolamento della Valcamonica fra tarda età del Ferro e romanizzazione. Insediamenti e luoghi di culto [PhD dissertation]. $\mathrm{Pa}-$ via: University of Pavia.

Solano S. 2008. L'area archeologica di Capo di Ponte (Brescia), loc. Le Sante: ustrinum o Brandopferplatz? Notizie Archeologiche Bergomensi 16:169-213.

Talon B. 1997. Etude anatomique et comparative de charbons de bois de Larix decidua Mill. et de Picea Abies (L.) Karst. Compte Rendu de l'Académie des Sciences de Paris. Sciences de la vie 320(7):581-8.
Taylor RE. 1987. Radiocarbon Dating: An Archaeological Perspective. Orlando: Academic Press.

Terrasi F, De Cesare N, D’Onofrio A, Lubritto C, Marzaioli F, Passariello I, Rogalla, D, Sabbarese C, Borriello G, Casa G, Palmieri A. 2008. High precision ${ }^{14} \mathrm{C}$ AMS at CIRCE. Nuclear Instruments and Methods in Physics Research B 266(10):2221-4.

Valvo A. 1991. La più antica testimonianza epigrafica della cristianizzazione della Valcamonica. Aevum 65: 211-20. 